\title{
Alzheimer's Disease and Epilepsy: A Perspective on the Opportunities for Overlapping Therapeutic Innovation
}

\author{
Leanne Lehmann ${ }^{1} \cdot$ Alexandria $\mathrm{Lo}^{2} \cdot$ Kevin M. Knox ${ }^{3} \cdot$ Melissa Barker-Haliski ${ }^{3}$
}

Received: 21 January 2021 / Revised: 16 April 2021 / Accepted: 20 April 2021 / Published online 30 April 2021

(c) The Author(s) 2021

\begin{abstract}
Early-onset Alzheimer's disease (AD) is associated with variants in amyloid precursor protein (APP) and presenilin (PSEN) 1 and 2. It is increasingly recognized that patients with $\mathrm{AD}$ experience undiagnosed focal seizures. These AD patients with reported seizures may have worsened disease trajectory. Seizures in epilepsy can also lead to cognitive deficits, neuroinflammation, and neurodegeneration. Epilepsy is roughly three times more common in individuals aged 65 and older. Due to the numerous available antiseizure drugs (ASDs), treatment of seizures has been proposed to reduce the burden of AD. More work is needed to establish the functional impact of seizures in AD to determine whether ASDs could be a rational therapeutic strategy. The efficacy of ASDs in aged animals is not routinely studied, despite the fact that the elderly represents the fastest growing demographic with epilepsy. This leaves a particular gap in understanding the discrete pathophysiological overlap between hyperexcitability and aging, and AD more specifically. Most of our preclinical knowledge of hyperexcitability in $\mathrm{AD}$ has come from mouse models that overexpress APP. While these studies have been invaluable, other drivers underlie AD, e.g. PSEN2. A diversity of animal models should be more frequently integrated into the study of hyperexcitability in $\mathrm{AD}$, which could be particularly beneficial to identify novel therapies. Specifically, AD-associated risk genes, in particular PSENs, altogether represent underexplored contributors to hyperexcitability. This review assesses the available studies of ASDs administration in clinical AD populations and preclinical studies with $\mathrm{AD}$-associated models and offers a perspective on the opportunities for further therapeutic innovation.
\end{abstract}

Keywords Epilepsy $\cdot$ Alzheimer's disease $\cdot$ Antiseizure drugs $\cdot$ Animal models $\cdot$ Cognitive decline

\section{Introduction}

Elderly patients represent the fastest growing demographic with epilepsy, and epilepsy is, in fact, an under recognized comorbidity of Alzheimer's disease (AD). The relative risk of unprovoked seizures markedly increases in patients with early-onset $\mathrm{AD}$, reaching up to 87 -fold greater risk

Leanne Lehmann and Alexandria Lo contributed equally to this work.

Melissa Barker-Haliski

mhaliski@uw.edu

1 Undergraduate Neuroscience Program, University of Washington, Seattle, WA 98195, USA

2 Department of Public Health-Global Health, School of Public Health, University of Washington, Seattle, WA 98195, USA

3 Department of Pharmacy, School of Pharmacy, University of Washington, Seattle, WA 98195, USA for seizures in individuals with $\mathrm{AD}$ onset between 50 and 59 years versus that of the general population [1]. Even lateonset $\mathrm{AD}$ patients have a greater incidence of unprovoked seizures relative to that which would be expected in similarly aged individuals (hazard ratio 8.06 ; $95 \%$ confidence interval 3.23-16.61 [2]). Silent hippocampal (focal) seizures have been reported in AD [3]; neuronal hyperexcitability is thus an underexplored contributor to the behavioral sequelae of AD. Epilepsy and AD also share many pathological similarities: temporal lobe atrophy, neuronal death, gliosis, neuritic alterations, and neuroinflammation [4-8]. Both are characterized by neuropsychiatric comorbidities-anxiety, aggression, and depression - that negatively impact quality of life. Both AD and epilepsy are associated with neuronal hyperexcitability; yet how seizures additively or secondarily contribute to the onset and severity of behavioral deficits in AD needs additional study. The purpose of this review is to thus assess the available studies of ASD use for seizures in clinical $\mathrm{AD}$ and preclinical studies with $\mathrm{AD}$-associated 
models, and offer a perspective on the untapped opportunities for further therapeutic innovation.

The precise mechanisms leading to the development of seizures in the setting of $\mathrm{AD}$ are still under investigation and in need of further study. Nonetheless, the mechanisms of seizure generation are well established in the epileptic brain [9]. Neuronal depolarization drives the opening of voltage-gated sodium and calcium channels in the presynaptic neuron, leading to presynaptic release of glutamate into the synaptic cleft (Fig. 1). Post-synaptic

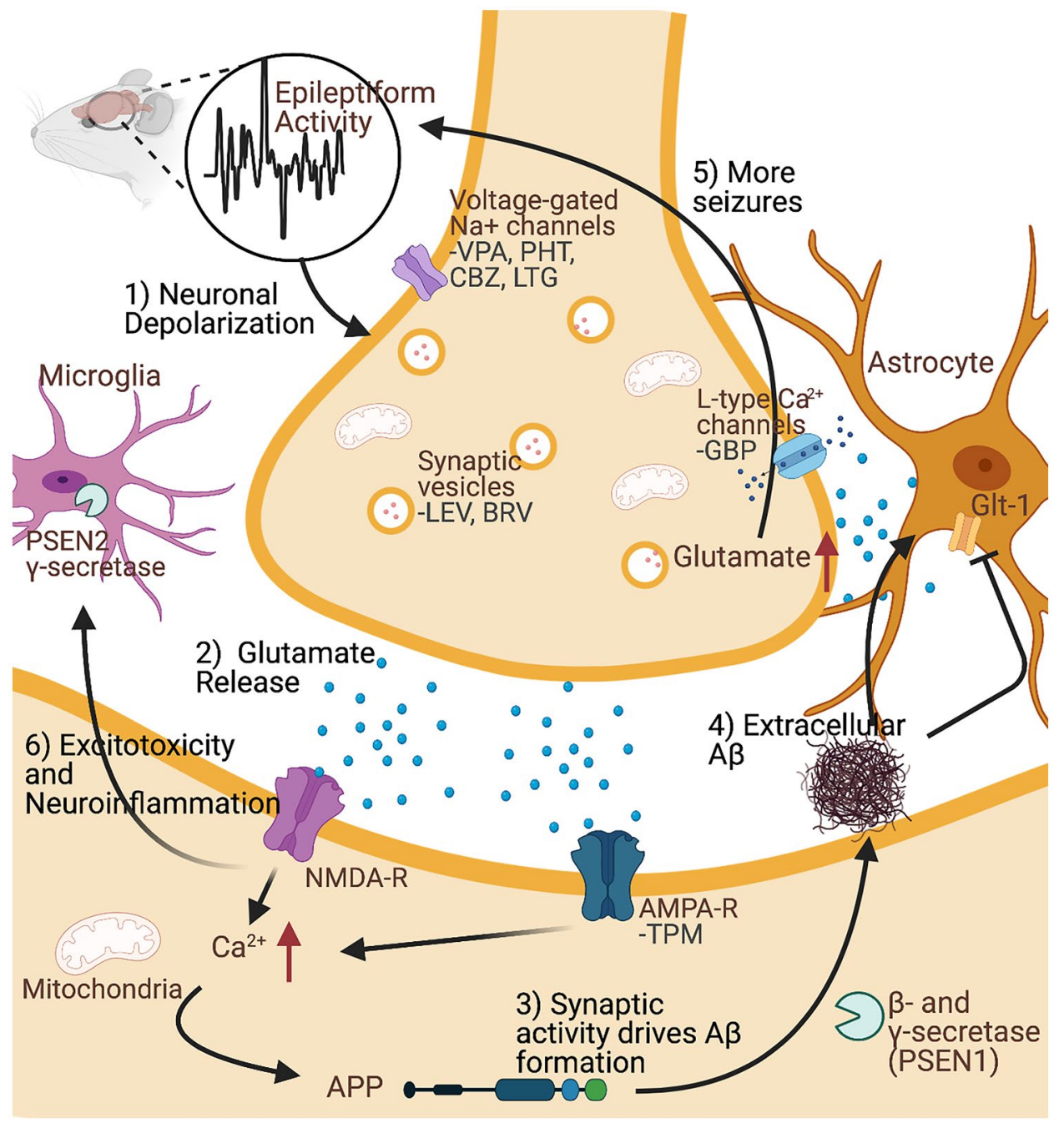

Fig. 1 There are numerous aspects of the excitatory synapse that can lead to seizures and disease worsening in Alzheimer's disease. (1) Through yet undetermined mechanisms, hyperactivity can lead to electrographic seizures that induce neuronal depolarization within hippocampal and cortical brain circuits. Neuronal depolarization leads first to sodium channel opening, and then calcium channel opening. (2) Depolarization induces vesicular trafficking and release of glutamate into the synapse. There, glutamate interacts with both NMDA- and AMPA-type receptors, driving increased intracellular $\mathrm{Ca}^{2+}$ levels. (3) High synaptic activity causes the cleavage of amyloid precursor protein (APP) by first $\beta$-, and then $\gamma$-secretase to generate $\beta$ - and $\gamma$-C-terminal fragments (CTFs) of APP essential to amyloid $\beta$ (A $\beta$ ) plaque formation. (4) Extracellular $A \beta$ induces further glutamate release from astrocytes, as well as blocks the astrocytic Glt-1 transporter that is essential for glutamate reuptake. This effectively increases the amount of glutamate within the neuronal synapse and potentiates NMDA receptor activation, leading to a cycle of neuronal activation and (5) more seizures. This excessive neuronal activity and glutamate-mediated excitotoxicity then further increases neuroinflammation and microglial activation. In the context of Alzheimer's disease, PSEN2 variants cause dysfunctional microglial response to neuroinflammation and can be proinflammatory, exacerbating neurodegeneration. Several approved antiseizure drugs have been assessed in preclinical $\mathrm{AD}$ models and their molecular targets within the excitatory synapse are depicted. This includes agents that act at sodium channels-valproic acid (VPA), carbamazepine (CBZ), phenytoin (PHT), lamotrigine (LTG); those that work at synaptic vesicles-levetiracetam (LEV) and brivaracetam (BRV); those that target $\mathrm{Ca}^{2+}$ channels-gabapentin (GBP); and those that act on AMPA-type glutamate receptors-topiramate (TPM). Nonetheless, there are numerous additional antiseizure drugs that work through alternative targets in the excitatory synapse that could be useful to attenuate hyperactivity and excitotoxic neurodegeneration. Created with BioRender.com 
$\alpha$-amino-3-hydroxy-5-methyl-4-isoxazolepropionic acid (AMPA)-type glutamate receptors (AMPARs) are critical to fast excitatory neurotransmission, whereas $\mathrm{N}$-methylD-aspartate (NMDA)-type glutamate receptors (NMDARs) mediate much of the slow excitatory potentials essential to global information processing. Glutamate can also interact with ionotropic kainate receptors (KAR), although the precise role of KARs in seizures and neuronal signaling is less clearly established [10]. Presynaptic sodium and calcium channels driving excitatory neurotransmission and postsynaptic glutamate receptors are thus generally relevant therapeutic targets in epilepsy. Further, sodium and calcium channels may contribute not only to seizure generation and maintenance, but also indirectly promote the excitotoxic neurodegeneration of AD through excessive glutamate release [11]. Indeed, the non-competitive NMDAR antagonist, memantine, does provide some degree of benefit in moderate- to severe-AD through the neuroprotective effects of reduced NMDA receptor activation and resulting reductions in the influx of calcium ions [12].

In addition to driving excitotoxic glutamate release, neuronal hyperexcitability may also promote expression of pathological drivers of AD (Fig. 1) causing further neurodegeneration. Synaptic activity drives the cleavage of amyloid precursor protein (APP; [13]) by first $\beta$-, then $\gamma$-, secretase to form amyloid- $\beta(\mathrm{A} \beta)$ plaques sequestered into the interstitial space [14]. A $\beta$ plaque accumulation is a pathological hallmark of $\mathrm{AD}$. Increased $\mathrm{A} \beta$ deposition further indirectly compounds glutamate neurotoxicity via effects on astrocytes (Fig. 1). Under normal conditions, astrocytes remove excess glutamate from the synaptic cleft via the excitatory amino acid transporter 2 (EAAT2/glutamate transporter-1 (Glt1 ; [9]). Accumulated $A \beta$ prevents the normal clearance of synaptic glutamate through Glt-1 [15], leading to excessive glutamate levels in the synaptic cleft to the point of extrasynaptic NMDAR activation driving excitotoxic cell death. $\mathrm{A} \beta$ also interacts with synaptic NMDARs and enhances calcium influx with neuronal depolarization [16]. Secondarily, $\mathrm{A} \beta$ plaque accumulation may lead to the misfolding of tau protein and aggregation, a neuronal microtubule-associated protein that plays a core role in axonal transport. Tau protein is hyperphosphorylated in $\mathrm{AD}$, disrupting normal neuronal functions. Accumulation of hyperphosphorylated tau protein leads to the neurofibrillary tangles that are a defining feature of clinical $\mathrm{AD}[17,18]$. Accumulation of neurofibrillary tangles can cause neurodegeneration and cognitive deficit. Thus, neuronal hyperactivity leads to a number of pathological changes in the AD brain that additively increase seizure susceptibility, promote excitotoxic neuronal death, and $A \beta$ accumulation (Fig. 1).

Seizure control with antiseizure drugs (ASDs) may be a potential strategy to reduce the burden of AD [19]. With over 30 FDA-approved ASDs [20], there is an untapped opportunity to repurpose ASDs to possibly curb the severity of AD. Indeed, efforts have been made in recent years to assess the potential disease-modifying effects of ASD administration in $\mathrm{AD}$, including findings that levetiracetam (LEV) may be disease-modifying [21-23]. However, insufficient clinical or preclinical studies have been conducted to definitively establish whether seizures in AD patients or animal models are not also sensitive to other ASDs. Moreover, the clinical studies that have been performed have not been uniformly conducted such that direct comparisons across studies is quite challenging. A considerable proportion of patients with epilepsy do not receive therapeutic benefit from available ASDs [24]. In this regard, preclinical models of $\mathrm{AD}$ are essential to simultaneously explore in greater detail the mechanisms associated with seizures in $\mathrm{AD}$ and potentially uncover novel treatments for hyperexcitability, not to mention rigorously establish the efficacy of ASDs in an aged AD-associated neurological substrate. The worldwide percentage of people aged over 65 is increasing considerably (Fig. 2a), but basic science has not sufficiently responded to address this clinical need. ASD discovery is not traditionally conducted in aged rodents [25-28]. Just as the use of juvenile Scnla \pm mice has uncovered novel treatments for Dravet syndrome (e.g., cannabidiol [29]), a rare pediatric epileptic encephalopathy, there is substantial opportunity to more frequently integrate aged animals, and in particular aged AD models, into ASD discovery to advance novel treatments and identify novel therapeutic targets (Fig. 2b). Clinical and preclinical evidence reveals a chance to prioritize ASD discovery for seizures in AD. Such efforts may also translate to improved treatments for epilepsy, in general. Seizures could be a manageable feature of AD [30-32] because seizures in the elderly are generally not drug-resistant [33]. However, it is essential to clearly establish the direct contribution of seizures on AD burden and neuropathology so that future preclinical and clinical trials can be more rationally and rigorously conducted.

\section{Clinical Efficacy of Antiseizure Drugs in Patients with Alzheimer's Disease}

The focal seizures in AD may be difficult to recognize [3, 31] and may even go undetected by surface EEG electrodes that only detect cortical activity [3]. Undetected seizures are untreated seizures. Whether the onset or severity of behavioral sequelae of $\mathrm{AD}$ is exacerbated by uncontrolled focal seizures is presently unclear. Synaptic activity itself can drive the release of $A \beta[14]$. It is therefore reasonable to presume that administration of ASDs could reduce the accumulation of $A \beta$ through the direct suppression of seizures and hyperexcitability (Fig. 1). 


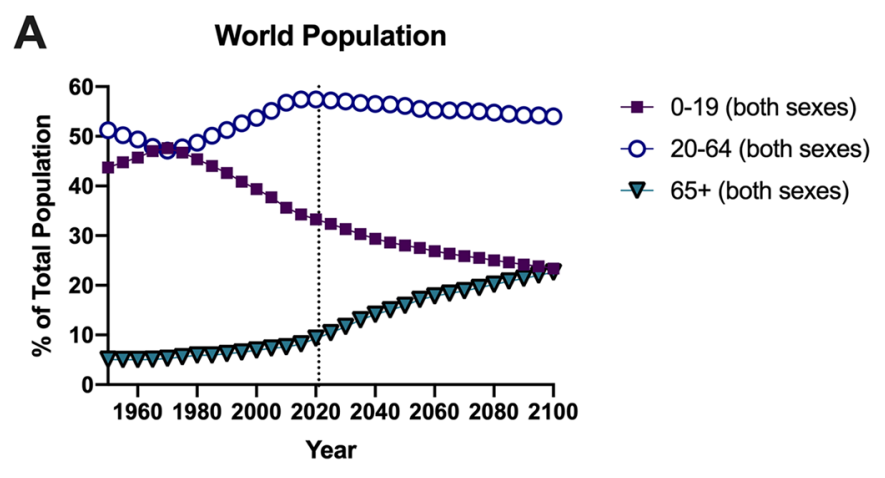

Fig. 2 a The percentage of people aged $65+$ has steadily increased as a total percentage of the global population since 1950. Children aged 0-19 represent a progressively smaller proportion of the global population whereas elderly people aged 65 increasingly make up a larger proportion of the worldwide population. Elderly patients represent the fastest growing demographic with epilepsy, likely as a result of the numerous inciting events that can cause epilepsy in the elderly (e.g., stroke, brain tumor, traumatic brain injury/falls). Dashed line at 2020 represents estimated populations going forward from UN Population database access date of December 14, 2020 (https://population. un.org/wpp/DataQuery/). b In the preclinical space, there has been

Limited studies have suggested that pharmacological control of focal seizures with ASDs administered to patients with $\mathrm{AD}$ may slow disease progression and reduce the severity of neuropsychiatric comorbidities [22]. Yet, the evidence that ASDs have therapeutic potential in clinical AD has been mixed (Table 1, [19]). Furthermore, there has been no standardized approach to patient enrollment, ASD selection, or trial methodology to rigorously assess the therapeutic potential of ASD administration in a homogenously defined AD patient population. Limited clinical evidence would suggest that ASDs carry the potential to improve cognitive function in mild cognitive impairment [21], highlighting an untapped opportunity to improve clinical management of AD. For example, in a randomized study, valproic acid (VPA; $10-12 \mathrm{mg} / \mathrm{kg} /$ day) or placebo was administered to 313 participants with moderate $\mathrm{AD}$ over 24 months (122 patients completed the study), yet the study concluded that VPA was associated with brain volume loss [34]. In another randomized study, 313 individuals with mild-to-moderate AD were given VPA (10-12 mg/kg/day) or placebo for a 24 -month period and again demonstrated a greater loss of hippocampal and brain volume in the VPA treatment group [35]. Furthermore, VPA administration led to adverse effects and no reduction in disease burden. VPA exerts a broad efficacy profile in patients with epilepsy and the precise mechanism by which it exerts an anticonvulsant effect is still unclear [20]; whether a specific molecular target could be more useful for the seizures in AD is currently unknown. Available evidence thus-far clearly does not indicate that

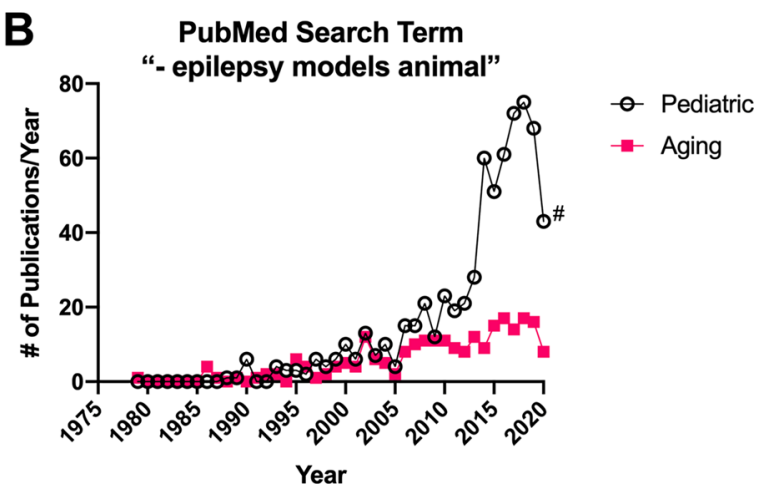

relative concordance between the publications with aged and pediatric animal models until approximately 2013-2014, likely as a result of several research initiatives (e.g., Citizens United for Research in Epilepsy Infantile Spasms Initiative, 2013 NINDS Curing the Epilepsies Meeting, etc.). Since this time, published studies using pediatric epilepsy models have significantly accelerated whereas similar publications with aged animal models of epilepsy has not similarly increased. This represents a significant gap in preclinical research that does not match the clinical patient demographic needs. \# indicates reporting of all studies published up until the Pubmed access date of December 14, 2020

all ASDs are the panacea for AD and that inappropriate ASD selection may, in fact, carry the potential to do further harm.

Rational selection of ASDs based on specific mechanism may instead be more beneficial in AD (Table 1). For example, LEV monotherapy (1000-1500 mg/day) in 25 patients with advanced $\mathrm{AD}$ and seizures demonstrated that $72 \%$ of patients remained seizure-free over 14-25 months, suggesting that LEV could improve seizure control in AD [36]. A different randomized prospective study of $95 \mathrm{AD}$ patients aged 60-90 years old with documented seizures was designed to compare the anticonvulsant efficacy of LEV $(\mathrm{n}=38)$, phenobarbital (PB; $\mathrm{n}=28)$, and lamotrigine (LTG; $\mathrm{n}=29$ ); there were no detectable differences in the 12-month change in seizure freedom and responder rate [22]. As a secondary objective, that study also assessed the cognitive impact of ASD administration to AD patients with seizures versus the cognitive performance of $A D$ patients without seizures [22]. PB evoked negative cognitive effects, LEV improved attention, short-term memory, and oral fluency, and LTG conferred better moods [22]. Sodium channelblocking ASDs, like LTG, have gained interest and off-label use for the management of impulsive aggression [37-39], suggesting that rationally selected ASDs may attenuate specific AD-associated neuropsychiatric symptoms. Pharmacological control of undetected focal seizures in AD with appropriately and rationally selected ASDs (e.g., LTG for neuropsychiatric deficits vs LEV for cognition) could potentially improve quality of life and prolong the period of independent function. LEV was developed as an enantiomer 


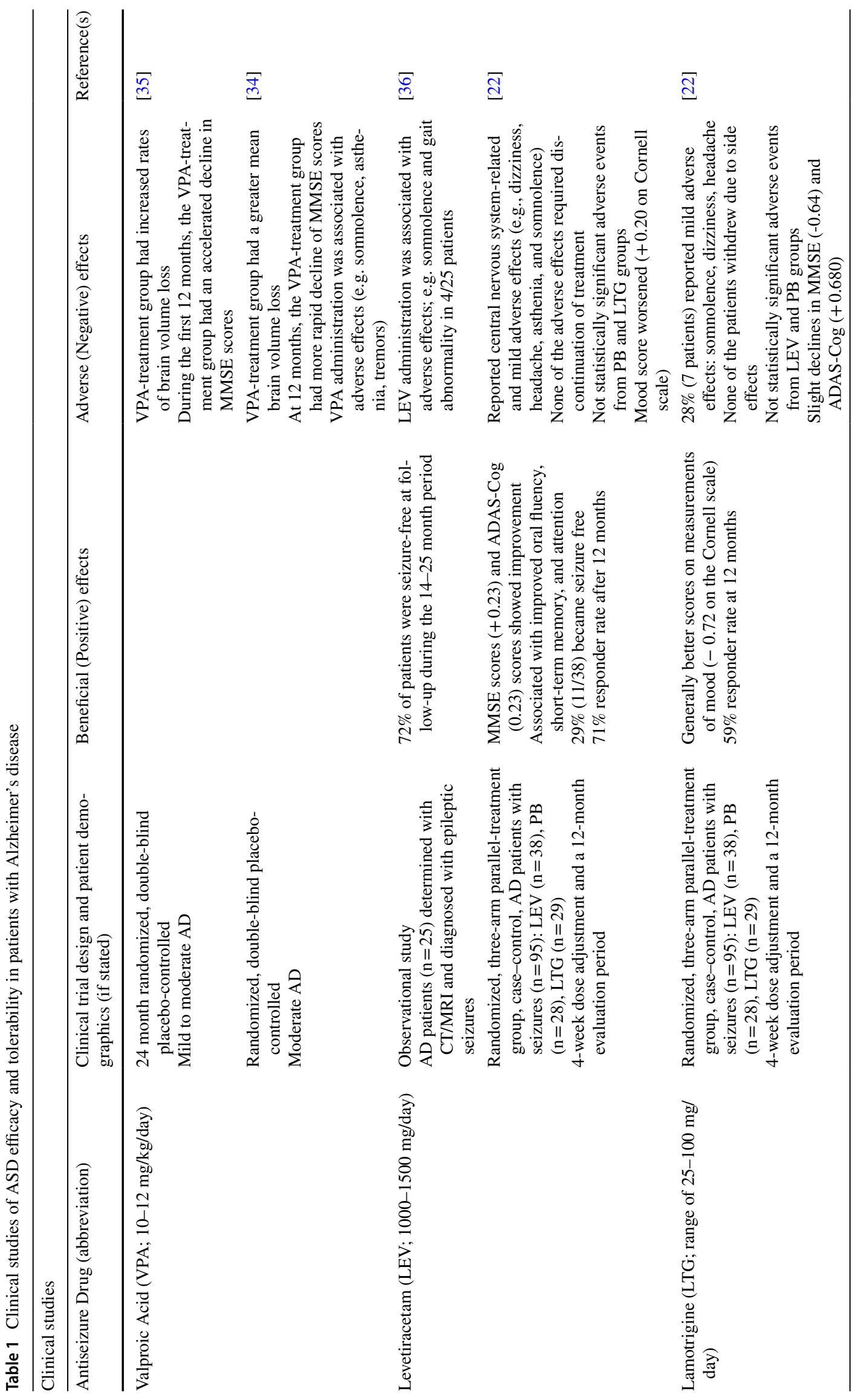






of the nootropic agent, piracetam [40], so studies to further elucidate the cognitive enhancing effects of LEV and related compounds (e.g. brivaracetam) in $\mathrm{AD}$ are warranted. However, whether LEV and LTG, or other ASD combinations, could additively or synergistically reduce the burden of comorbidities of AD must be first rigorously established in well-controlled clinical trials. Studies in AD patients should also be prioritized to assess the antiseizure potential of newer ASDs (e.g. cannabidiol) that have been found to benefit cognitive function in patients with epilepsy [41] or animal epilepsy models [42].

ASD use in the elderly is already high; at least $10 \%$ of nursing home residents take at least one ASD [43-45]. Older adults with chronic conditions pose a particular prescribing challenge due to the high potential for drug-drug interactions [46], which can limit medication adherence due to adverse drug effects and/or adversely affect disease outcomes. Careful selection of ASDs in elderly populations is particularly important because many of the available ASDs can alter the metabolism and/or bioavailability of drugs that are also prescribed for other aging-related conditions [47]. For example, in a random sample of $5 \%$ of Medicare beneficiaries collected from 2008 to 2010, roughly 1 in 4 incident cases of epilepsy received an ASD in combination with at least one non-ASD that could adversely affect pharmacokinetic interactions between the agents [46]. In particular, over $50 \%$ of older adults with epilepsy continue to use phenytoin (PHT) after 12 months [48], yet PHT is associated with high potential for drug-drug interactions in this population [46]. Moreover, poor adherence to specific medications by older adults can also put individuals at a higher risk of dementia [49]. Elderly patients with seizures are thus a particularly challenging group for drug treatment due to the numerous potential risks associated with polypharmacy. Selection of ASDs in combination with other medications used in this patient population should be carefully and rigorously assessed with both predictive animal models and carefully designed clinical studies, prior to widespread clinical implementation in patients with or at risk for $\mathrm{AD}$.

\section{Preclinical Models of Aging and Epilepsy Should Address Clinical Needs}

Despite the greater incidence of epilepsy in elderly individuals and increased risk of comorbid seizures in $\mathrm{AD}$ patients, few aged animal seizure and epilepsy models have been sufficiently characterized to support drug discovery for aging-related seizures [50]. Comparative pharmacology with prototypical ASDs has not been extensively collected in the available animal models of $\mathrm{AD}$ to inform on the potential pharmacokinetic, toxicity, or drug interactions in aged or geriatric populations. This is in stark contrast to the 
rigorous evaluation of comparative pharmacology in rodent drug-resistant epilepsy models [26, 51-53]. Information concerning the risk of seizure in rodents with $\mathrm{AD}$-associated mutations would support their utility for moderate- to highthroughput preclinical approaches for drug development for aged and geriatric patients with seizures. Mouse strain alone can significantly impact seizure threshold [54], as can age [55], but whether there are additive effects of aging and AD-associated mutations on seizure susceptibility or ASD efficacy should be more comprehensively assessed.

Preclinical models are invaluable to predict tolerability and pharmacokinetics in a specific population, e.g. aged individuals. However, the ASDs on the market were brought forth based on efficacy in young adult, neurologically intact wild-type rodents [56]. Preclinical information concerning the efficacy and safety of investigational agents is not routinely defined in aged animals with seizures $[28,56]$. While there has been a recent explosion in available preclinical models of pediatric epilepsy used for ASD discovery (Fig. 2b), there has not been a similar rise in the use of aged animals. Rodents with $\mathrm{AD}$-associated variants are simply not used for ASD identification or differentiation [57]. Safety and tolerability of FDA-approved ASDs in aged individuals has been established in clinical trials [58-60], even though aged rodents share many of the age-related physiological changes of humans [61] and could be important surrogates to predict tolerability for this demographic. For example, we detect marked tremors in aged mice acutely treated with high doses of LTG [62], an adverse effect also reported in elderly patients treated with LTG [63]. It is plausible that use of aged rodents for ASD tolerability testing could have predicted such observations, as has already been done with other rodent epilepsy models $[64,65]$. As a result, the management of seizures in elderly patients, including those with seizures in $\mathrm{AD}$, may be underinformed.

Preclinical studies have defined the cognitive profile, baseline EEG activity, and changes in synaptic morphology associated with APP overexpression at a single age in mice [66-68], yet the basic understanding of age-related susceptibility to seizures in the presence of AD-associated risk genes is still relatively undefined. Rodent models with early onset-AD-associated variants are particularly valuable to define how hyperexcitability may be associated with $\mathrm{AD}$ throughout life. While the age of $\mathrm{AD}$ onset varies markedly based on the specific genetic variant, the pathology and clinical course of early-onset $\mathrm{AD}$ is similar to that of sporadic AD [69]. Early-onset AD is associated with point mutations or indels within PSEN1, PSEN2 or APP genes, or with a duplication of APP. However, the majority of our preclinical knowledge of hyperexcitability in AD has come from mice that overexpress APP [23, 67]. While spontaneous seizures are well-tolerated in most APP/PS1 mice, $38 \%$ of animals can succumb to seizure-related mortality [68], constraining resources and driving up costs for moderatethroughput ASD discovery [57]. Thus, models that overexpress early-onset AD-associated APP variants have been helpful to explore the manifestation of hyperexcitability in $\mathrm{AD}$, but there still remains a need to establish whether and how other drivers of AD affect seizures and disease course.

There is scattered preclinical data assessing the impact of ASDs on disease burden in a diversity of AD models; that which is available also predominantly focuses on the effects of ASDs on behaviors in models that overexpress APP as a result of early-onset AD-associated genetic variants. Furthermore, studies conducted thus far do not consistently nor uniformly apply anticonvulsant doses of ASDs to discretely interrogate antiseizure versus disease-modifying effects (Table 2). For example, chronic (4-week) administration of low dose VPA to 7- to 9-month-old APP23 transgenic mice reduced neuritic plaques (i.e. amyloid plaques) by $56-76 \%$ and improved spatial memory. A similar course of VPA administered to 6-week-old APP23/PS45 doubletransgenic mice (which express presenilin-1 with G384A variant) resulted in a nearly $80 \%$ reduction in plaques [70]. However, the dose of VPA $(30 \mathrm{mg} / \mathrm{kg}$, i.p., q.i.d.) used in either strain was far below that which acutely blocks focal seizures in wild-type C57Bl/6 mice (169-276 mg/kg, i.p.) [51], including similarly aged C57Bl/6 mice $(186 \mathrm{mg} / \mathrm{kg}$, i.p.) [62]. The frequency of administration (once/day) was also insufficient to attain steady-state seizure suppression with such a rapidly metabolized ASD in mice [71]. Thus, the effects of once-daily VPA administration on A $\beta$ plaques in APP23 and APP23/PS45 mice was likely not due to direct seizure control $[72,73]$. Repeated once-daily i.p. administration of topiramate $(20 \mathrm{mg} / \mathrm{kg}), \mathrm{LEV}(50 \mathrm{mg} / \mathrm{kg})$, or VPA $(30 \mathrm{mg} / \mathrm{kg}$ ) to 7 -month-old APP/PS1 mice reduced A $\beta$ plaques by $45.8 \%, 51.9 \%$, and $53.1 \%$ respectively, and attenuated behavioral deficits [74]. However, as with the studies by Qing and colleagues [70], the doses and frequency of topiramate and LEV administration of [74] were well below the acutely anticonvulsant doses in mice [71], suggesting that any disease-modification was not directly attributable to prevention of electrographic seizures.

Studies that have directly assessed the antiseizure effects of ASDs in preclinical models with AD-associated genotypes are even more limited (Table 2). These studies have consistently relied on APP overexpressing mouse models. The doses that were assessed in such studies were not also uniformly applied to encompass an anticonvulsant range. Ziyatdinova and colleagues demonstrated a beneficial dose-related effect of VPA (30 vs $300 \mathrm{mg} / \mathrm{kg}$, i.p.) on spontaneous electrographic discharges (EDs) in APP/ PS1 mice [75]. Yet, there was no associated effect of VPA $(300 \mathrm{mg} / \mathrm{kg})$ on soluble and insoluble $A \beta$ levels in that study [75]. Low-dose LEV (20-75 mg/kg) has been found to consistently suppress spontaneous EDs in APP/PS1 [72, 







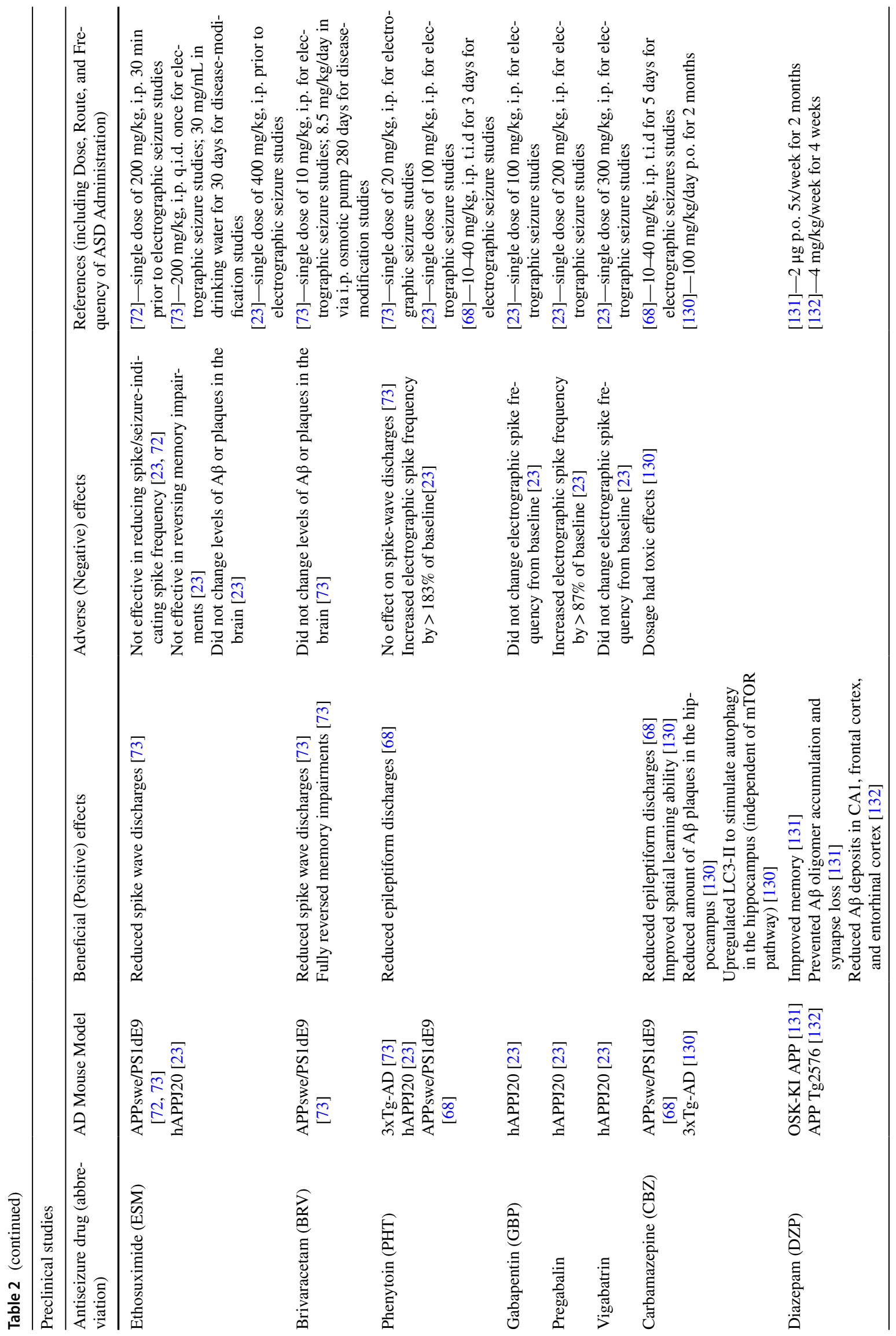




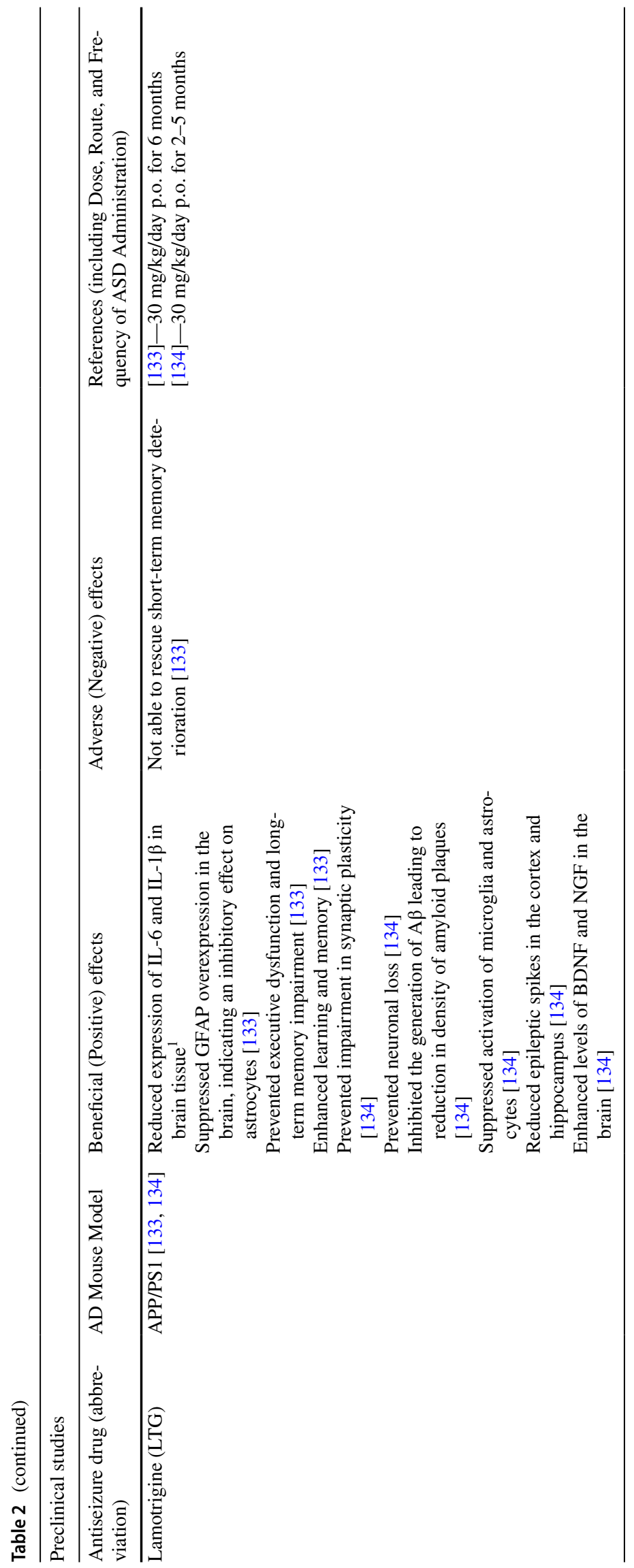


73] and hAPPJ20 mice [23]. This dose range of LEV is anticonvulsant against focal seizures in young and aged C57Bl/6 mice [51, 62]. Acute administration of the T-type calcium channel blocker, ethosuximide (ESM; $200 \mathrm{mg} / \mathrm{kg}$ ), can also reduce EDs in APP/PS1 mice [72, 73] but high dose ESM $(400 \mathrm{mg} / \mathrm{kg})$ is ineffective in hAPPJ 20 mice [23]. This dose of ESM is also acutely anticonvulsant in a mouse audiogenic seizure model of reflex seizure [71] and myoclonic seizures [76]. Brivaracetam $(8.5 \mathrm{mg} / \mathrm{kg} /$ day for 28 days) has been shown to not only reduce EDs, but reverse memory impairments in APP/PS1 mice [73], likely due to anticonvulsant effects on EDs. Notably, brivaracetam has a superior profile of brain bioavailability in rodents, more rapid penetration into the brain, and is substantially more potent than LEV in numerous acute seizure models in male mice, including this $8.5 \mathrm{mg} / \mathrm{kg} /$ day dose $[77,78]$. Certainly, some specific ASDs have been found to effectively suppress seizures in mouse AD models.

The spontaneous seizures of APP/PS1 mice aged 4- to 6-months-old were also found to be sensitive to repeated administration of anticonvulsant doses of the sodium channel-blocking ASDs, carbamazepine (CBZ) and phenytoin (PHT), and the broad spectrum ASD, VPA [68]. However, that study also demonstrated that high dose administration of the sodium channel-blocking ASDs (40 mg/kg CBZ; $40 \mathrm{mg} / \mathrm{kg}$ PHT) worsened the electrographic discharges of 1-3 individual mice [68], consistent with later findings with similarly high dose of PHT $(40 \mathrm{mg} / \mathrm{kg})$ in hAPPJ 20 mice [23]. While these findings for seizure worsening with high dose administration of sodium channel blocking ASDs is at first glance concerning for a mouse model of $\mathrm{AD}$, it is well established that sodium channel blockers can lower seizure threshold at high doses [76, 79], thus care should be taken to not over interpret these findings as specific to AD models. Lastly, Jin and colleagues have also more recently demonstrated an effect of ESM $(200 \mathrm{mg} /$ $\mathrm{kg})$ and LEV $(75 \mathrm{mg} / \mathrm{kg}$ ) on state-dependent spike-wave discharges (SWDs) in aged APP/PS1 mice [80]. This study highlights the capacity to evaluate the efficacy of ASDs on specific types of epileptiform activity that is also observed in genetically susceptible rat models of absence epilepsy $[57,81,82]$. There is scattered evidence that ASDs can effectively reduce spontaneous EDs and SWDs in mice that overexpress APP. However, the studies have not been uniformly conducted using well-established principles for pharmacological studies [51], and the outcome measures have been mixed, clouding interpretation of any findings and limiting translational impact. Additional studies to comprehensively assess whether anticonvulsant doses of other ASDs affect seizures in other AD-associated models that do not exclusively overexpress APP are also needed.

\section{Overlapping Molecular Targets in Epilepsy and Alzheimer's Disease}

In addition to the shared pathophysiology between seizures and $\mathrm{AD}$, which can potentially worsen functional outcomes, these disorders share several similarities in molecular drivers of disease that warrant further study. The formation of $\mathrm{A} \beta$ plaques as a result of pathological neuronal hyperactivity and cleavage of APP by first $\beta$-, and then $\gamma$-secretase to generate $\beta$ - and $\gamma$-C-terminal fragments (CTFs) of APP is essential to A $\beta$ plaque formation produces a key clinical feature of AD (Fig. 1). However, the $\alpha$-secretase A Disintegrin And Metalloprotease 10 (ADAM10) is involved in a secondary and understudied pathway of APP processing that releases the soluble portion $(\mathrm{sA} \beta \mathrm{PP} \alpha)$ and prevents the formation of senile plaques [83]. In this manner, ADAM10 may actually be protective in $\mathrm{AD}$ and prevent the formation of senile plaques. Interestingly, ADAM10 has been implicated in the pathogenesis of focal cortical dysplasia $[84,85]$, a disease characterized by epileptic seizures and neurocognitive deficit. Overexpression of ADAM10 in a mouse temporal lobe epilepsy model also attenuates the burden of seizures and prevents pathological neuroinflammation [86]. While no ASD has yet been shown to affect the ADAM10 pathway, this work highlights that this alternative pathway underlying pathogenesis in both epilepsy and $\mathrm{AD}$ is a potential avenue for therapeutic intervention.

Both epilepsy and AD are increasingly viewed as disorders associated with significant metabolic dysfunction. Glucose hypometabolism is commonly observed in both clinical [87] and preclinical studies [88] of AD, as is the compensatory shift to alternative fuel sources, e.g. ketone bodies [89-91]. Reduced glucose utilization in the hippocampus and entorhinal cortex, two brain regions also heavily implicated in temporal lobe epilpesy, correlates to cognitive deficits over time in normal aged individuals, and can also predict those individuals who go on to develop mild cognitive impairment [92]. Oxidative stress is often reported in preclinical models of temporal lobe epilepsy in adult rodents [93]. Moreover, the aged brain itself may also undergo significant shifts in normal bioenergetics processes; aged individuals utilize glucose to alternative fuel sources (e.g. ketone bodies) at a ratio of 29:1, whereas young individuals exclusively utilize glucose at a ratio of 100:0 [94]. In patients with $\mathrm{AD}$, this ratio of glucose to alternative fuel consumption is $2: 1$ [94]. Thus, age-related shifts in glucose metabolism may contribute to both epilepsy and AD. Further, reducing glycolysis in both patients with epilepsy and animal models using 2-deoxy-D-glucose (2DG) has been found to be quite effective as an anticonvulsant strategy $[95,96]$. Thus, 
metabolic regulation through pharmacological or dietary manipulation is an overlapping therapeutic target for both epilepsy and $\mathrm{AD}$, as well as potentially affecting the hyperexcitability associated with seizures in patients with AD.

\section{Presenilins are an Underexplored Molecular Contributor to Seizures in AD}

Early-onset AD is also associated with PSEN1 and PSEN2 variants [97]. Presenilins are intramembrane proteases of the catalytic component of $\gamma$-secretase; mutations of which promote the formation of cleavage products such as $\mathrm{A} \beta$ (Fig. 1; $[69,98])$. There is high incidence of seizures $(32 \%)$ in $\mathrm{AD}$ patients with the most common PSEN2 variant (N141I), although these events are only self-reported and no chronic monitoring for electrographic (focal) seizures has yet been exclusively conducted in this patient group [99]. Moreover, similar to case reports in other patients with early-onset AD $[3,19,32]$, it is entirely plausible that focal seizures are more frequent with PSEN2 variants than generalized seizures that would be readily detected by a caregiver, underscoring the need for more detailed clinical monitoring. PSEN2 is also particularly intriguing to explore the hyperexcitability of $\mathrm{AD}$ because some PSEN2 variants are associated with reduced penetrance [100], such that cases may be inadvertently masked as sporadic AD [101].

PSEN2 is attractive to define the additive impact of aging and seizures on disease burden in AD. First, PSENs may more meaningfully influence neuropsychiatric symptoms of AD [102]. Second, PSEN2 is a key contributor underlying neuroinflammation [103, 104]; loss of normal PSEN2 function disrupts canonical $\gamma$-secretase activity to promote a proinflammatory phenotype mediated by microglial activation and cytokine release [104, 105]. Microglial activation and cytokine release can also promote the development of epilepsy [106, 107]. Use of PSEN2 transgenic versus APP overexpression models $[67,108]$ allows for the interrogation of the role that an altered neuroinflammatory milieu may play on seizure susceptibility and burden of AD. Third, PSEN2 variants cause $A D$ with later onset than PSEN1 variants (AD Mutation database: https://www.alzforum.org/mutat ions), making PSEN2 variant models suitable to simultaneously interrogate the additive environmental impacts of senescence [109] and neuronal hyperexcitability on disease outcomes. Fourth, PSEN2 variants do not induce A $\beta$ accumulation in mice [110] and APP processing [111], unlike APP/PS1 transgenic mouse models [112, 113], affording an opportunity to define whether $A \beta$ accumulation and/or seizures are more detrimental to the onset and severity of behavioral sequelae. Finally, PSEN2 is essential to mitochondrial-dependent $\mathrm{Ca}^{2+}$ homeostasis underlying normal neuronal signaling $[114,115]$. Specifically, PSEN2, but not
PSEN1, regulates the tethering and $\mathrm{Ca}^{2+}$ crosstalk between the endoplasmic reticulum and mitochondria, which may itself alter cellular bioenergetics or increase mitochondriadependent cell death [115]. The early-onset AD-associated PSEN2-N141I variant, but not normal PSEN2 or PSEN1, can potentiate mitochondrial dysfunction [116]. Neuronal hyperexcitability due to dysregulation of $\mathrm{Ca}^{2+}$ release may be one of the first observable biomarkers in the aged and diseased brain and is consistently observed in rodent models of AD [117-119] and epilepsy [120]. Altogether, PSEN2 mouse models should be increasingly integrated into studies of seizures and hyperexcitability in $\mathrm{AD}$ to interrogate pathological processes of AD that are distinct from extraneous $\mathrm{A} \beta$ production.

Mouse PSEN2 variant models are an untapped opportunity to further elucidate the mechanism of seizures in AD. It is clear that APP overexpression in mice has revealed significant pathophysiological overlap between AD and epilepsy $[67,121]$; yet few studies have extensively evaluated whether other AD risk genes (e.g., PSENs) are similarly associated with changes in seizure susceptibility, seizureinduced functional impacts, or ASD efficacy. Recently, we have begun to explore age-related seizure susceptibility in mice with loss of normal PSEN2 function. We observe an age-related change in the development of kindled seizures, a model of epileptogenesis [81], in PSEN2 knockout (KO) mice [62]. PSEN2 variants in AD lead to a loss of normal $\gamma$-secretase activity, such that PSEN2 KO mice are useful to a priori assess how loss of normal PSEN2 function influences seizure susceptibility. Young PSEN2 KO mice were less susceptible to formation of an epileptic network than aged PSEN2 KO mice [62], implicating an age-related change in neuronal excitability and susceptibility to chronic seizures with loss of normal PSEN2 function. The latency to develop corneal kindled seizures in 2-month-old PSEN2 KO mice was significantly longer than age- and sex-matched WT mice; an effect that was lost in mice aged $>8$ months [62]. Notably, the seizure duration of mice with fully kindled seizures was significantly longer in young PSEN2 KO mice, despite requiring more corneal stimulations to achieve the fully kindled state. The seizures of young male fully kindled PSEN2 KO mice were also less sensitive to escalating doses of LEV and diazepam (DZP) than age-matched WT mice, as well as the fully kindled PSEN2 KO mice aged greater than 8-months old. Thus, corneal kindling of PSEN2 $\mathrm{KO}$ mice is a technically feasible way to assess the potential for anticonvulsant efficacy, identify novel contributors to ictogenesis, and assess age-related changes in seizure susceptibility. In addition to assessing kindling acquisition rates of young and mature PSEN2 KO mice, we assessed the age-related changes in seizure susceptibility using two acute seizure tests: the minimal clonic and $6 \mathrm{~Hz}$ seizure models [62]. Importantly, these studies established the 
feasibility of using well-established, moderate-throughput acute and chronic seizure models $[26,57]$ to PSEN2 KO mice to define how AD-associated risk factors impact ASD efficacy and seizure susceptibility. PSEN2 variant models can be highly informative to more thoroughly understand how seizures and ASDs are tolerated in the aged rodent brain.

\section{Conclusions and Future Directions}

Considerable understanding of the hyperexcitability and seizures in AD has come from small clinical studies [3] and preclinical work primarily with early-onset $\mathrm{AD}$-associated APP-overexpressing mice [23, 67]. However, the intersection between seizures and AD remains relatively underexplored. Numerous therapeutic targets bridge the intersection between both disorders; additional study is clearly warranted. PSEN2 variants are highly associated with seizures within 5 years of AD diagnosis; this incidence matches that which is associated with APP duplications and is more common than that which is observed with PSEN1 variants [122]. As a result, PSENs, and PSEN2 in particular, should be more frequently studied in isolation to interrogate the effects of PSEN2 variants on seizures in AD. Mice with PSEN2 variants do not demonstrate $A \beta$ plaques [110]. PSEN2 variant models are intriguing to study the pathological intersection between seizures in AD because of the role for PS2 protein that is independent from its $\gamma$-secretase activity. In this regard, PSEN2 is an untapped opportunity to define the contributions that $A \beta$-independent mechanisms may play in the hyperexcitability of AD. PSEN2 manipulation may additionally reveal novel molecular contributors to ictogenesis [123]. There is reason to believe that novel therapies for $\mathrm{AD}$ and epilepsy could be bidirectionally uncovered [124]. Basic science has generated a remarkable diversity of preclinical models of AD that have advanced our understanding of its pathophysiological processes. Now, it is incumbent that we further expand the application of these models to comorbid conditions (e.g., epilepsy) to best inform the clinical management and further elucidate the mechanisms of hyperexcitability and its influence on $\mathrm{AD}$ trajectory. Prioritizing the studies of seizures in a diversity of AD models will better inform future ASD discovery for elderly patients.

Author Contributions LL, AL, KMK, and MBH all contributed to the drafting of this manuscript.

Funding This work was supported by ITHS KL2 (KL2TR002317), American Epilepsy Society Junior Investigator Awards, and 5R01AG067788 to MBH.

\section{Declarations}

Conflict of interest The authors declare that the research was conducted in the absence of any commercial or financial relationships that could be construed as a potential conflict of interest.

Open Access This article is licensed under a Creative Commons Attribution 4.0 International License, which permits use, sharing, adaptation, distribution and reproduction in any medium or format, as long as you give appropriate credit to the original author(s) and the source, provide a link to the Creative Commons licence, and indicate if changes were made. The images or other third party material in this article are included in the article's Creative Commons licence, unless indicated otherwise in a credit line to the material. If material is not included in the article's Creative Commons licence and your intended use is not permitted by statutory regulation or exceeds the permitted use, you will need to obtain permission directly from the copyright holder. To view a copy of this licence, visit http://creativecommons.org/licenses/by/4.0/.

\section{References}

1. Amatniek JC, Hauser WA, DelCastillo-Castaneda C, Jacobs DM, Marder K, Bell K, Albert M, Brandt J, Stern Y (2006) Incidence and predictors of seizures in patients with Alzheimer's disease. Epilepsia 47(5):867-872. https://doi.org/10.1111/j.1528-1167. 2006.00554.x

2. Scarmeas N, Honig LS, Choi H, Cantero J, Brandt J, Blacker D, Albert M, Amatniek JC, Marder K, Bell K, Hauser WA, Stern Y (2009) Seizures in Alzheimer disease: who, when, and how common? Arch Neurol 66(8):992-997. https://doi.org/10.1001/ archneurol.2009.130

3. Lam AD, Deck G, Goldman A, Eskandar EN, Noebels J, Cole AJ (2017) Silent hippocampal seizures and spikes identified by foramen ovale electrodes in Alzheimer's disease. Nat Med 23(6):678-680. https://doi.org/10.1038/nm.4330

4. Ackermann RF, Engel J Jr, Phelps ME (1986) Identification of seizure-mediating brain structures with the deoxyglucose method: studies of human epilepsy with positron emission tomography, and animal seizure models with contact autoradiography. Adv Neurol 44:921-934

5. Buckmaster PS, Dudek FE (1997) Neuron loss, granule cell axon reorganization, and functional changes in the dentate gyrus of epileptic kainate-treated rats. J Comp Neurol 385(3):385-404

6. Cook MJ, Fish DR, Shorvon SD, Straughan K, Stevens JM (1992) Hippocampal volumetric and morphometric studies in frontal and temporal lobe epilepsy. Brain 115(Pt 4):1001-1015

7. Fazekas F, Alavi A, Chawluk JB, Zimmerman RA, Hackney D, Bilaniuk L, Rosen M, Alves WM, Hurtig HI, Jamieson DG et al (1989) Comparison of CT, MR, and PET in Alzheimer's dementia and normal aging. J Nucl Med 30(10):1607-1615

8. Struble RG, Ala T, Patrylo PR, Brewer GJ, Yan XX (2010) Is brain amyloid production a cause or a result of dementia of the Alzheimer's type? J Alzheimers Dis 22(2):393-399. https://doi. org/10.3233/JAD-2010-100846

9. Barker-Haliski M, White HS (2015) Glutamatergic mechanisms associated with seizures and epilepsy. Cold Spring Harb Perspect Med 5(8):a022863. https://doi.org/10.1101/cshperspect.a022863

10. Falcon-Moya R, Sihra TS, Rodriguez-Moreno A (2018) Kainate receptors: role in epilepsy. Front Mol Neurosci 11:217. https:// doi.org/10.3389/fnmol.2018.00217

11. Esposito Z, Belli L, Toniolo S, Sancesario G, Bianconi C, Martorana A (2013) Amyloid beta, glutamate, excitotoxicity in 
Alzheimer's disease: are we on the right track? CNS Neurosci Ther 19(8):549-555. https://doi.org/10.1111/cns.12095

12. Kabir MT, Sufian MA, Uddin MS, Begum MM, Akhter S, Islam A, Mathew B, Islam MS, Amran MS, Md Ashraf G (2019) NMDA receptor antagonists: repositioning of memantine as a multitargeting agent for Alzheimer's therapy. Curr Pharm Des 25(33):3506-3518. https://doi.org/10.2174/138161282566619 1011102444

13. Kamenetz F, Tomita T, Hsieh H, Seabrook G, Borchelt D, Iwatsubo T, Sisodia S, Malinow R (2003) APP processing and synaptic function. Neuron 37(6):925-937. https://doi.org/10.1016/ s0896-6273(03)00124-7

14. Cirrito JR, Yamada KA, Finn MB, Sloviter RS, Bales KR, May PC, Schoepp DD, Paul SM, Mennerick S, Holtzman DM (2005) Synaptic activity regulates interstitial fluid amyloid-beta levels in vivo. Neuron 48(6):913-922. https://doi.org/10.1016/j.neuron. 2005.10.028

15. Zott B, Simon MM, Hong W, Unger F, Chen-Engerer HJ, Frosch MP, Sakmann B, Walsh DM, Konnerth A (2019) A vicious cycle of beta amyloid-dependent neuronal hyperactivation. Science 365(6453):559-565. https://doi.org/10.1126/science.aay0198

16. Fu W, Ruangkittisakul A, MacTavish D, Shi JY, Ballanyi K, Jhamandas JH (2012) Amyloid beta (Abeta) peptide directly activates amylin-3 receptor subtype by triggering multiple intracellular signaling pathways. J Biol Chem 287(22):18820-18830. https://doi.org/10.1074/jbc.M111.331181

17. Grundke-Iqbal I, Iqbal K, Quinlan M, Tung YC, Zaidi MS, Wisniewski HM (1986) Microtubule-associated protein tau. A component of Alzheimer paired helical filaments. J Biol Chem 261(13):6084-6089

18. Grundke-Iqbal I, Iqbal K, Tung YC, Quinlan M, Wisniewski HM, Binder LI (1986) Abnormal phosphorylation of the microtubuleassociated protein tau (tau) in Alzheimer cytoskeletal pathology. Proc Natl Acad Sci USA 83(13):4913-4917. https://doi.org/10. 1073/pnas.83.13.4913

19. Vossel KA, Tartaglia MC, Nygaard HB, Zeman AZ, Miller BL (2017) Epileptic activity in Alzheimer's disease: causes and clinical relevance. The Lancet Neurology 16(4):311-322. https://doi. org/10.1016/S1474-4422(17)30044-3

20. Sills GJ, Rogawski MA (2020) Mechanisms of action of currently used antiseizure drugs. Neuropharmacology 168:107966. https:// doi.org/10.1016/j.neuropharm.2020.107966

21. Bakker A, Krauss GL, Albert MS, Speck CL, Jones LR, Stark CE, Yassa MA, Bassett SS, Shelton AL, Gallagher M (2012) Reduction of hippocampal hyperactivity improves cognition in amnestic mild cognitive impairment. Neuron 74(3):467-474. https://doi.org/10.1016/j.neuron.2012.03.023

22. Cumbo E, Ligori LD (2010) Levetiracetam, lamotrigine, and phenobarbital in patients with epileptic seizures and Alzheimer's disease. Epilepsy Behav 17(4):461-466. https://doi.org/10.1016/j. yebeh.2010.01.015

23. Sanchez PE, Zhu L, Verret L, Vossel KA, Orr AG, Cirrito JR, Devidze N, Ho K, Yu GQ, Palop JJ, Mucke L (2012) Levetiracetam suppresses neuronal network dysfunction and reverses synaptic and cognitive deficits in an Alzheimer's disease model. Proc Natl Acad Sci USA 109(42):E2895-2903. https://doi.org/ 10.1073/pnas.1121081109

24. Chen Z, Brodie MJ, Liew D, Kwan P (2018) Treatment outcomes in patients with newly diagnosed epilepsy treated with established and new antiepileptic drugs: a 30-year longitudinal cohort study. JAMA Neurol 75(3):279-286. https://doi.org/10. 1001/jamaneurol.2017.3949

25. Barker-Haliski M (2019) How do we choose the appropriate animal model for antiseizure therapy development? Expert Opin Drug Discov. https://doi.org/10.1080/17460441.2019.1636782
26. Barker-Haliski ML, Johnson K, Billingsley P, Huff J, Handy LJ, Khaleel R, Lu Z, Mau MJ, Pruess TH, Rueda C, Saunders G, Underwood TK, Vanegas F, Smith MD, West PJ, Wilcox KS (2017) Validation of a preclinical drug screening platform for pharmacoresistant epilepsy. Neurochem Res 42(7):1904-1918. https://doi.org/10.1007/s11064-017-2227-7

27. Kehne JH, Klein BD, Raeissi S, Sharma S (2017) The National Institute of Neurological Disorders and Stroke (NINDS) Epilepsy Therapy Screening Program (ETSP). Neurochem Res. https://doi. org/10.1007/s11064-017-2275-Z

28. Wilcox KS, West PJ, Metcalf CS (2019) The current approach of the epilepsy therapy screening program contract site for identifying improved therapies for the treatment of pharmacoresistant seizures in epilepsy. Neuropharmacology. https://doi.org/10. 1016/j.neuropharm.2019.107811

29. Kaplan JS, Stella N, Catterall WA, Westenbroek RE (2017) Cannabidiol attenuates seizures and social deficits in a mouse model of Dravet syndrome. Proc Natl Acad Sci USA 114(42):11229-11234. https://doi.org/10.1073/pnas.17113 51114

30. Cretin B, Sellal F, Philippi N, Bousiges O, Di Bitonto L, Martin-Hunyadi C, Blanc F (2016) Epileptic prodromal Alzheimer's disease, a retrospective study of 13 new cases: expanding the spectrum of Alzheimer's disease to an epileptic variant? J Alzheimers Dis 52(3):1125-1133. https://doi.org/10.3233/ JAD-150096

31. Lam AD, Pellerin K, Gomperts S, Cole AJ, Cash SS SUBCLINICAL EPILEPTIFORM ABNORMALITIES IN PATIENTS WITH LATE-ONSET ALZHEIMER'S DISEASE. In: American Epilepsy Society Annual Meeting, Washington, D.C., December 4, 2017 2017b. p Abst. 3.084

32. Vossel KA, Beagle AJ, Rabinovici GD, Shu H, Lee SE, Naasan G, Hegde M, Cornes SB, Henry ML, Nelson AB, Seeley WW, Geschwind MD, Gorno-Tempini ML, Shih T, Kirsch HE, Garcia PA, Miller BL, Mucke L (2013) Seizures and epileptiform activity in the early stages of Alzheimer disease. JAMA Neurol 70(9):1158-1166. https://doi.org/10.1001/jamaneurol.2013.136

33. Hernandez-Ronquillo L, Adams S, Ballendine S, Tellez-Zenteno JF (2018) Epilepsy in an elderly population: classification, etiology and drug resistance. Epilepsy Res 140:90-94. https://doi.org/ 10.1016/j.eplepsyres.2017.12.016

34. Tariot PN, Schneider LS, Cummings J, Thomas RG, Raman R, Jakimovich LJ, Loy R, Bartocci B, Fleisher A, Ismail MS, Porsteinsson A, Weiner M, Jack CR Jr, Thal L, Aisen PS, Alzheimer's Disease Cooperative Study G (2011) Chronic divalproex sodium to attenuate agitation and clinical progression of Alzheimer disease. Arch Gen Psychiatry 68(8):853-861. https://doi.org/ 10.1001/archgenpsychiatry.2011.72

35. Fleisher AS, Truran D, Mai JT, Langbaum JB, Aisen PS, Cummings JL, Jack CR Jr, Weiner MW, Thomas RG, Schneider LS, Tariot PN, Alzheimer's Disease Cooperative S (2011) Chronic divalproex sodium use and brain atrophy in Alzheimer disease. Neurology 77(13):1263-1271. https://doi.org/10.1212/WNL. 0b013e318230a16c

36. Belcastro V, Costa C, Galletti F, Pisani F, Calabresi P, Parnetti L (2007) Levetiracetam monotherapy in Alzheimer patients with late-onset seizures: a prospective observational study. Eur J Neurol 14(10):1176-1178. https://doi.org/10.1111/j.1468-1331.2007. 01907.x

37. Barratt ES, Stanford MS, Felthous AR, Kent TA (1997) The effects of phenytoin on impulsive and premeditated aggression: a controlled study. J Clin Psychopharmacol 17(5):341-349

38. Gobbi G, Debonnel G (2003) What is a recommended treatment for aggression in a patient with schizophrenia? J Psychiatry Neurosci 28(4):320 
39. Stanford MS, Anderson NE, Lake SL, Baldridge RM (2009) Pharmacologic treatment of impulsive aggression with antiepileptic drugs. Curr Treat Options Neurol 11(5):383-390

40. Genton P, Van Vleymen B (2000) Piracetam and levetiracetam: close structural similarities but different pharmacological and clinical profiles. Epileptic Disord 2(2):99-105

41. Lagae L, Sullivan J, Knupp K, Laux L, Polster T, Nikanorova M, Devinsky O, Cross JH, Guerrini R, Talwar D, Miller I, Farfel G, Galer BS, Gammaitoni A, Mistry A, Morrison G, Lock M, Agarwal A, Lai WW, Ceulemans B, Group FADS (2019) Fenfluramine hydrochloride for the treatment of seizures in Dravet syndrome: a randomised, double-blind, placebo-controlled trial. Lancet 394(10216):2243-2254. https://doi.org/10.1016/S01406736(19)32500-0

42. Patra PH, Barker-Haliski M, White HS, Whalley BJ, Glyn S, Sandhu H, Jones N, Bazelot M, Williams CM, McNeish AJ (2019) Cannabidiol reduces seizures and associated behavioral comorbidities in a range of animal seizure and epilepsy models. Epilepsia 60(2):303-314. https://doi.org/10.1111/epi.14629

43. Cloyd JC, Lackner TE, Leppik IE (1994) Antiepileptics in the elderly Pharmacoepidemiology and pharmacokinetics. Arch Fam Med 3(7):589-598

44. Garrard J, Cloyd J, Gross C, Hardie N, Thomas L, Lackner T, Graves N, Leppik I (2000) Factors associated with antiepileptic drug use among elderly nursing home residents. J Gerontol A 55(7):M384-392

45. Lackner TE, Cloyd JC, Thomas LW, Leppik IE (1998) Antiepileptic drug use in nursing home residents: effect of age, gender, and comedication on patterns of use. Epilepsia 39(10):1083-1087

46. Faught E, Szaflarski JP, Richman J, Funkhouser E, Martin RC, Piper K, Dai C, Juarez L, Pisu M (2018) Risk of pharmacokinetic interactions between antiepileptic and other drugs in older persons and factors associated with risk. Epilepsia 59(3):715-723. https://doi.org/10.1111/epi.14010

47. Brodie MJ, Mintzer S, Pack AM, Gidal BE, Vecht CJ, Schmidt D (2013) Enzyme induction with antiepileptic drugs: cause for concern? Epilepsia 54(1):11-27. https://doi.org/10.1111/j.15281167.2012.03671.x

48. Arif H, Buchsbaum R, Pierro J, Whalen M, Sims J, Resor SR Jr, Bazil CW, Hirsch LJ (2010) Comparative effectiveness of 10 antiepileptic drugs in older adults with epilepsy. Arch Neurol 67(4):408-415. https://doi.org/10.1001/archneurol.2010.49

49. Marcum ZA, Walker RL, Jones BL, Ramaprasan A, Gray SL, Dublin S, Crane PK, Larson EB (2019) Patterns of antihypertensive and statin adherence prior to dementia: findings from the adult changes in thought study. BMC Geriatr 19(1):41. https:// doi.org/10.1186/s12877-019-1058-6

50. Kelly KM (2010) Aging models of acute seizures and epilepsy. Epilepsy Curr 10(1):15-20. https://doi.org/10.1111/j.1535-7511. 2009.01341.x

51. Koneval Z, Knox KM, Memon A, Zierath DK, White HS, BarkerHaliski M (2020b) Antiseizure drug efficacy and tolerability in established and novel drug discovery seizure models in outbred versus inbred mice. Epilepsia (In press)

52. Leclercq K, Kaminski RM (2015) Genetic background of mice strongly influences treatment resistance in the $6 \mathrm{~Hz}$ seizure model. Epilepsia 56(2):310-318. https://doi.org/10.1111/epi. 12893

53. Leclercq K, Matagne A, Kaminski RM (2014) Low potency and limited efficacy of antiepileptic drugs in the mouse $6 \mathrm{~Hz}$ corneal kindling model. Epilepsy Res 108(4):675-683. https://doi.org/ 10.1016/j.eplepsyres.2014.02.013

54. Frankel WN, Taylor L, Beyer B, Tempel BL, White HS (2001) Electroconvulsive thresholds of inbred mouse strains. Genomics 74(3):306-312
55. Engstrom FL, White HS, Kemp JW, Woodbury DM (1986) Acute and chronic acetazolamide administration in DBA and C57 mice: effects of age. Epilepsia 27(1):19-26

56. Barker-Haliski M, White HS (2015) Antiepileptic drug development and experimental models. In: Wyllie E, Gidal BE, Goodkin HP (eds) Wyllie's Treatment of Epilepsy, 6th edn. Lippencott, Williams \& Wilkins, Philadelphia

57. Barker-Haliski M, White HS (2019) Validated animal models for antiseizure drug (ASD) discovery: advantages and potential pitfalls in ASD screening. Neuropharmacology. https://doi.org/ 10.1016/j.neuropharm.2019.107750

58. Birnbaum AK, Leppik IE, Svensden K, Eberly LE (2017) Prevalence of epilepsy/seizures as a comorbidity of neurologic disorders in nursing homes. Neurology 88(8):750-757. https://doi.org/ 10.1212/WNL.0000000000003629

59. Conway JM, Eberly LE, Collins JF, Macias FM, Ramsay RE, Leppik IE, Birnbaum AK (2017) Factors in variability of serial gabapentin concentrations in elderly patients with epilepsy. Pharmacotherapy 37(10):1197-1203. https://doi.org/10.1002/ phar.2012

60. Polepally AR, Brundage RC, Remmel RP, Leppik IE, Pennell PB, White JR, Ramsay RE, Kistner BM, Birnbaum AK (2018) Lamotrigine pharmacokinetics following oral and stablelabeled intravenous administration in young and elderly adult epilepsy patients: effect of age. Epilepsia 59(9):1718-1726. https://doi.org/10.1111/epi.14519

61. Yang HC, Zuo Y, Fogo AB (2010) Models of chronic kidney disease. Drug Discov Today Dis Models 7(1-2):13-19. https:// doi.org/10.1016/j.ddmod.2010.08.002

62. Beckman M, Knox K, Koneval Z, Smith C, Jayadev S, BarkerHaliski M (2020) Loss of presenilin 2 age-dependently alters susceptibility to acute seizures and kindling acquisition. Neurobiol Dis 136:104719. https://doi.org/10.1016/j.nbd.2019. 104719

63. Polepally AR, Brundage RC, Remmel RP, Leppik IE, Pennell PB, White JR, Ramsay RE, Kistner BM, Birnbaum AK (2018) Lamotrigine pharmacokinetics following oral and stable-labeled intravenous administration in young and elderly adult epilepsy patients: effect of age. Epilepsia. https://doi.org/10.1111/epi.14519

64. Klitgaard H, Matagne A, Lamberty Y (2002) Use of epileptic animals for adverse effect testing. Epilepsy Res 50(1-2):55-65

65. Simonato M, Loscher W, Cole AJ, Dudek FE, Engel J Jr, Kaminski RM, Loeb JA, Scharfman H, Staley KJ, Velisek L, Klitgaard H (2012) Finding a better drug for epilepsy: preclinical screening strategies and experimental trial design. Epilepsia 53(11):18601867. https://doi.org/10.1111/j.1528-1167.2012.03541.x

66. Minkeviciene R, Rheims S, Dobszay MB, Zilberter M, Hartikainen J, Fulop L, Penke B, Zilberter Y, Harkany T, Pitkanen A, Tanila H (2009) Amyloid beta-induced neuronal hyperexcitability triggers progressive epilepsy. J Neurosci 29(11):3453-3462. https://doi.org/10.1523/JNEUROSCI.5215-08.2009

67. Palop JJ, Chin J, Roberson ED, Wang J, Thwin MT, Bien-Ly N, Yoo J, Ho KO, Yu GQ, Kreitzer A, Finkbeiner S, Noebels JL, Mucke L (2007) Aberrant excitatory neuronal activity and compensatory remodeling of inhibitory hippocampal circuits in mouse models of Alzheimer's disease. Neuron 55(5):697-711. https://doi.org/10.1016/j.neuron.2007.07.025

68. Ziyatdinova S, Gurevicius K, Kutchiashvili N, Bolkvadze T, Nissinen J, Tanila H, Pitkanen A (2011) Spontaneous epileptiform discharges in a mouse model of Alzheimer's disease are suppressed by antiepileptic drugs that block sodium channels. Epilepsy Res 94(1-2):75-85. https://doi.org/10.1016/j.eplep syres.2011.01.003

69. De Strooper B, Iwatsubo T, Wolfe MS (2012) Presenilins and gamma-secretase: structure, function, and role in Alzheimer 
disease. Cold Spring Harb Perspect Med 2(1):a006304. https:// doi.org/10.1101/cshperspect.a006304

70. Qing H, He G, Ly PT, Fox CJ, Staufenbiel M, Cai F, Zhang Z, Wei S, Sun X, Chen CH, Zhou W, Wang K, Song W (2008) Valproic acid inhibits Abeta production, neuritic plaque formation, and behavioral deficits in Alzheimer's disease mouse models. J Exp Med 205(12):2781-2789. https://doi.org/10.1084/jem.20081 588

71. Bialer M, Twyman RE, White HS (2004) Correlation analysis between anticonvulsant ED50 values of antiepileptic drugs in mice and rats and their therapeutic doses and plasma levels. Epilepsy Behav 5(6):866-872

72. Gureviciene I, Ishchenko I, Ziyatdinova S, Jin N, Lipponen A, Gurevicius K, Tanila H (2019) Characterization of epileptic spiking associated with brain amyloidosis in APP/PS1 mice. Front Neurol 10:1151. https://doi.org/10.3389/fneur.2019.01151

73. Nygaard HB, Kaufman AC, Sekine-Konno T, Huh LL, Going H, Feldman SJ, Kostylev MA, Strittmatter SM (2015) Brivaracetam, but not ethosuximide, reverses memory impairments in an Alzheimer's disease mouse model. Alzheimers Res Ther 7(1):25. https://doi.org/10.1186/s13195-015-0110-9

74. Shi JQ, Wang BR, Tian YY, Xu J, Gao L, Zhao SL, Jiang T, Xie HG, Zhang YD (2013) Antiepileptics topiramate and levetiracetam alleviate behavioral deficits and reduce neuropathology in APPswe/PS1dE9 transgenic mice. CNS Neurosci Ther 19(11):871-881. https://doi.org/10.1111/cns.12144

75. Ziyatdinova S, Viswanathan J, Hiltunen M, Tanila H, Pitkanen A (2015) Reduction of epileptiform activity by valproic acid in a mouse model of Alzheimer's disease is not long-lasting after treatment discontinuation. Epilepsy Res 112:43-55. https://doi. org/10.1016/j.eplepsyres.2015.02.005

76. Piredda SG, Woodhead JH, Swinyard EA (1985) Effect of stimulus intensity on the profile of anticonvulsant activity of phenytoin, ethosuximide and valproate. J Pharmacol Exp Ther 232(3):741-745

77. Klitgaard H, Matagne A, Nicolas JM, Gillard M, Lamberty Y, De Ryck M, Kaminski RM, Leclercq K, Niespodziany I, Wolff C, Wood M, Hannestad J, Kervyn S, Kenda B (2016) Brivaracetam: rationale for discovery and preclinical profile of a selective SV2A ligand for epilepsy treatment. Epilepsia 57(4):538-548. https:// doi.org/10.1111/epi.13340

78. Nicolas JM, Hannestad J, Holden D, Kervyn S, Nabulsi N, Tytgat D, Huang Y, Chanteux H, Staelens L, Matagne A, Mathy FX, Mercier J, Stockis A, Carson RE, Klitgaard H (2016) Brivaracetam, a selective high-affinity synaptic vesicle protein $2 \mathrm{~A}$ (SV2A) ligand with preclinical evidence of high brain permeability and fast onset of action. Epilepsia 57(2):201-209. https:// doi.org/10.1111/epi.13267

79. Loscher W (2009) Preclinical assessment of proconvulsant drug activity and its relevance for predicting adverse events in humans. Eur J Pharmacol 610(1-3):1-11. https://doi.org/10. 1016/j.ejphar.2009.03.025

80. Jin N, Ziyatdinova S, Gureviciene I, Tanila H (2020) Response of spike-wave discharges in aged APP/PS1 Alzheimer model mice to antiepileptic, metabolic and cholinergic drugs. Sci Rep 10(1):11851. https://doi.org/10.1038/s41598-020-68845-y

81. Loscher W (2016) Fit for purpose application of currently existing animal models in the discovery of novel epilepsy therapies. Epilepsy Res 126:157-184. https://doi.org/10.1016/j.eplepsyres. 2016.05.016

82. Marescaux C, Vergnes M (1995) Genetic Absence Epilepsy in Rats from Strasbourg (GAERS). Ital J Neurol Sci 16(1-2):113-118

83. Manzine PR, Ettcheto M, Cano A, Busquets O, Marcello E, Pelucchi S, Di Luca M, Endres K, Olloquequi J, Camins A,
Cominetti MR (2019) ADAM10 in Alzheimer's disease: pharmacological modulation by natural compounds and its role as a peripheral marker. Biomed Pharmacother 113:108661. https:// doi.org/10.1016/j.biopha.2019.108661

84. Prox J, Bernreuther C, Altmeppen H, Grendel J, Glatzel M, D'Hooge R, Stroobants S, Ahmed T, Balschun D, Willem M, Lammich S, Isbrandt D, Schweizer M, Horre K, De Strooper B, Saftig P (2013) Postnatal disruption of the disintegrin/metalloproteinase ADAM10 in brain causes epileptic seizures, learning deficits, altered spine morphology, and defective synaptic functions. J Neurosci 33(32):12915-12928. https://doi.org/10.1523/ JNEUROSCI.5910-12.2013

85. Zhou X, Tao H, Cai Y, Cui L, Zhao B, Li K (2019) Stage-dependent involvement of ADAM10 and its significance in epileptic seizures. J Cell Mol Med 23(7):4494-4504. https://doi.org/10. 1111/jcmm.14307

86. Zhu X, Li X, Zhu M, Xu K, Yang L, Han B, Huang R, Zhang A, Yao H (2018) Metalloprotease Adam10 suppresses epilepsy through repression of hippocampal neuroinflammation. J Neuroinflammation 15(1):221. https://doi.org/10.1186/ s12974-018-1260-z

87. Mosconi L (2005) Brain glucose metabolism in the early and specific diagnosis of Alzheimer's disease. FDG-PET studies in MCI and AD. Eur J Nucl Med Mol Imaging 32(4):486-510. https:// doi.org/10.1007/s00259-005-1762-7

88. Mosconi L, Pupi A, De Leon MJ (2008) Brain glucose hypometabolism and oxidative stress in preclinical Alzheimer's disease. Ann N Y Acad Sci 1147:180-195. https://doi.org/10.1196/ annals.1427.007

89. Ding F, Yao J, Rettberg JR, Chen S, Brinton RD (2013) Early decline in glucose transport and metabolism precedes shift to ketogenic system in female aging and Alzheimer's mouse brain: implication for bioenergetic intervention. PLoS ONE 8(11):e79977. https://doi.org/10.1371/journal.pone.0079977

90. Klosinski LP, Yao J, Yin F, Fonteh AN, Harrington MG, Christensen TA, Trushina E, Brinton RD (2015) White matter lipids as a Ketogenic fuel supply in aging female brain: implications for Alzheimer's disease. EBioMedicine 2(12):1888-1904. https:// doi.org/10.1016/j.ebiom.2015.11.002

91. Yao J, Irwin RW, Zhao L, Nilsen J, Hamilton RT, Brinton RD (2009) Mitochondrial bioenergetic deficit precedes Alzheimer's pathology in female mouse model of Alzheimer's disease. Proc Natl Acad Sci USA 106(34):14670-14675. https://doi.org/10. 1073/pnas.0903563106

92. de Leon M, Bobinski M, Convit A, Wolf O, Insausti R (2001) Usefulness of MRI measures of entorhinal cortex versus hippocampus in AD. Neurology 56(6):820-821

93. Bhuyan P, Patel DC, Wilcox KS, Patel M (2015) Oxidative stress in murine Theiler's virus-induced temporal lobe epilepsy. Exp Neurol 271:329-334. https://doi.org/10.1016/j.expneurol.2015. 06.012

94. Hoyer S, Nitsch R, Oesterreich K (1991) Predominant abnormality in cerebral glucose utilization in late-onset dementia of the Alzheimer type: a cross-sectional comparison against advanced late-onset and incipient early-onset cases. J Neural Transm Park Dis Dement Sect 3(1):1-14

95. Rho JM, Shao LR, Stafstrom CE (2019) 2-deoxyglucose and beta-hydroxybutyrate: metabolic agents for seizure control. Front Cell Neurosci 13:172. https://doi.org/10.3389/fncel.2019.00172

96. Stafstrom CE, Ockuly JC, Murphree L, Valley MT, Roopra A, Sutula TP (2009) Anticonvulsant and antiepileptic actions of 2-deoxy-D-glucose in epilepsy models. Ann Neurol 65(4):435447. https://doi.org/10.1002/ana.21603

97. Jiang H, Jayadev S, Lardelli M, Newman M (2018) A review of the familial Alzheimer's disease locus PRESENILIN 2 and its 
relationship to PRESENILIN 1. J Alzheimers Dis 66(4):13231339. https://doi.org/10.3233/JAD-180656

98. Wiley JC, Hudson M, Kanning KC, Schecterson LC, Bothwell M (2005) Familial Alzheimer's disease mutations inhibit gammasecretase-mediated liberation of beta-amyloid precursor protein carboxy-terminal fragment. J Neurochem 94(5):1189-1201. https://doi.org/10.1111/j.1471-4159.2005.03266.x

99. Jayadev S, Leverenz JB, Steinbart E, Stahl J, Klunk W, Yu CE, Bird TD (2010) Alzheimer's disease phenotypes and genotypes associated with mutations in presenilin 2. Brain 133(Pt 4):11431154. https://doi.org/10.1093/brain/awq033

100. Finckh U, Alberici A, Antoniazzi M, Benussi L, Fedi V, Giannini C, Gal A, Nitsch RM, Binetti G (2000) Variable expression of familial Alzheimer disease associated with presenilin 2 mutation M239I. Neurology 54(10):2006-2008. https://doi.org/10.1212/ wnl.54.10.2006

101. Blauwendraat C, Wilke C, Jansen IE, Schulte C, Simon-Sanchez J, Metzger FG, Bender B, Gasser T, Maetzler W, Rizzu P, Heutink P, Synofzik M (2016) Pilot whole-exome sequencing of a German early-onset Alzheimer's disease cohort reveals a substantial frequency of PSEN2 variants. Neurobiol Aging 37:208. https://doi.org/10.1016/j.neurobiolaging.2015.09.016

102. Yan L, Li L, Han W, Pan B, Xue X, Mei B (2013) Age-related neuropsychiatric symptoms in presenilins conditional double knockout mice. Brain Res Bull 97:104-111. https://doi.org/10. 1016/j.brainresbull.2013.06.002

103. Jayadev S, Case A, Alajajian B, Eastman AJ, Moller T, Garden GA (2013) Presenilin 2 influences miR146 level and activity in microglia. J Neurochem 127(5):592-599. https://doi.org/10. $1111 /$ jnc. 12400

104. Jayadev S, Case A, Eastman AJ, Nguyen H, Pollak J, Wiley JC, Moller T, Morrison RS, Garden GA (2010) Presenilin 2 is the predominant gamma-secretase in microglia and modulates cytokine release. PLoS ONE 5(12):e15743. https://doi.org/10. 1371/journal.pone.0015743

105. Fung S, Smith CL, Prater KE, Case A, Green K, Osnis L, Winston C, Kinoshita Y, Sopher B, Morrison RS, Garden GA, Jayadev S (2020) Early-onset familial Alzheimer disease variant PSEN2 N141I heterozygosity is associated with altered microglia phenotype. J Alzheimers Dis 77(2):675-688. https://doi.org/10. 3233/JAD-200492

106. Barker-Haliski ML, Heck TD, Dahle EJ, Vanegas F, Pruess TH, Wilcox KS, White HS (2016) Acute treatment with minocycline, but not valproic acid, improves long-term behavioral outcomes in the theiler's virus model of temporal lobe epilepsy. Epilepsia (in press)

107. Vezzani A, Fujinami RS, White HS, Preux PM, Blumcke I, Sander JW, Loscher W (2015) Infections, inflammation and epilepsy. Acta Neuropathol. https://doi.org/10.1007/ s00401-015-1481-5

108. Palop JJ, Mucke L (2009) Epilepsy and cognitive impairments in Alzheimer disease. Arch Neurol 66(4):435-440. https://doi. org/10.1001/archneurol.2009.15

109. Gladyshev VN (2016) Aging: progressive decline in fitness due to the rising deleteriome adjusted by genetic, environmental, and stochastic processes. Aging Cell 15(4):594-602. https://doi.org/ 10.1111/acel.12480

110. Elder GA, Gama Sosa MA, De Gasperi R, Dickstein DL, Hof PR (2010) Presenilin transgenic mice as models of Alzheimer's disease. Brain Struct Funct 214(2-3):127-143. https://doi.org/ 10.1007/s00429-009-0227-3

111. Herreman A, Hartmann D, Annaert W, Saftig P, Craessaerts K, Serneels L, Umans L, Schrijvers V, Checler F, Vanderstichele H, Baekelandt V, Dressel R, Cupers P, Huylebroeck D, Zwijsen A, Van Leuven F, De Strooper B (1999) Presenilin 2 deficiency causes a mild pulmonary phenotype and no changes in amyloid precursor protein processing but enhances the embryonic lethal phenotype of presenilin 1 deficiency. Proc Natl Acad Sci USA 96(21):11872-11877

112. Minkeviciene R, Banerjee P, Tanila H (2004) Memantine improves spatial learning in a transgenic mouse model of Alzheimer's disease. J Pharmacol Exp Ther 311(2):677-682. https:// doi.org/10.1124/jpet.104.071027

113. Oksman M, Iivonen H, Hogyes E, Amtul Z, Penke B, Leenders I, Broersen L, Lutjohann D, Hartmann T, Tanila H (2006) Impact of different saturated fatty acid, polyunsaturated fatty acid and cholesterol containing diets on beta-amyloid accumulation in APP/PS1 transgenic mice. Neurobiol Dis 23(3):563-572. https:// doi.org/10.1016/j.nbd.2006.04.013

114. Leissring MA, Parker I, LaFerla FM (1999) Presenilin-2 mutations modulate amplitude and kinetics of inositol 1 , 4,5-trisphosphate-mediated calcium signals. J Biol Chem 274(46):32535-32538

115. Zampese E, Fasolato C, Kipanyula MJ, Bortolozzi M, Pozzan T, Pizzo P (2011) Presenilin 2 modulates endoplasmic reticulum (ER)-mitochondria interactions and $\mathrm{Ca} 2+$ cross-talk. Proc Natl Acad Sci USA 108(7):2777-2782. https://doi.org/10.1073/pnas. 1100735108

116. Filadi R, Greotti E, Turacchio G, Luini A, Pozzan T, Pizzo P (2016) Presenilin 2 modulates endoplasmic reticulum-mitochondria coupling by tuning the antagonistic effect of mitofusin 2 . Cell Rep 15(10):2226-2238. https://doi.org/10.1016/j.celrep. 2016.05.013

117. Agostini M, Fasolato C (2016) When, where and how? Focus on neuronal calcium dysfunctions in Alzheimer's Disease. Cell Calcium 60(5):289-298. https://doi.org/10.1016/j.ceca.2016.06. 008

118. Busche MA, Grienberger C, Keskin AD, Song B, Neumann U, Staufenbiel M, Forstl H, Konnerth A (2015) Decreased amyloidbeta and increased neuronal hyperactivity by immunotherapy in Alzheimer's models. Nat Neurosci 18(12):1725-1727. https:// doi.org/10.1038/nn.4163

119. Stargardt A, Swaab DF, Bossers K (2015) Storm before the quiet: neuronal hyperactivity and Abeta in the presymptomatic stages of Alzheimer's disease. Neurobiol Aging 36(1):1-11. https://doi. org/10.1016/j.neurobiolaging.2014.08.014

120. Dibue M, Kamp MA, Alpdogan S, Tevoufouet EE, Neiss WF, Hescheler J, Schneider T (2013) Ca 2.3 (R-type) calcium channels are critical for mediating anticonvulsive and neuroprotective properties of lamotrigine in vivo. Epilepsia. https://doi.org/10. 1111/epi. 12250

121. Vogt DL, Thomas D, Galvan V, Bredesen DE, Lamb BT, Pimplikar SW (2011) Abnormal neuronal networks and seizure susceptibility in mice overexpressing the APP intracellular domain. Neurobiol Aging 32(9):1725-1729. https://doi.org/10.1016/j. neurobiolaging.2009.09.002

122. Zarea A, Charbonnier C, Rovelet-Lecrux A, Nicolas G, Rousseau S, Borden A, Pariente J, Le Ber I, Pasquier F, Formaglio M, Martinaud O, Rollin-Sillaire A, Sarazin M, Croisile B, Boutoleau-Bretonniere C, Ceccaldi M, Gabelle A, Chamard L, Blanc F, Sellal F, Paquet C, Campion D, Hannequin D, Wallon D, Collaborators PG (2016) Seizures in dominantly inherited Alzheimer disease. Neurology 87(9):912-919. https://doi.org/10. 1212/WNL.0000000000003048

123. Wu L, Li Y, Yu M, Yang F, Tu M, Xu H (2018) Notch signaling regulates microglial activation and inflammatory reactions in a rat model of temporal lobe epilepsy. Neurochem Res 43(6):12691282. https://doi.org/10.1007/s11064-018-2544-5

124. Damar U, Gersner R, Johnstone JT, Schachter S, Rotenberg A (2017) Huperzine A: a promising anticonvulsant, disease modifying, and memory enhancing treatment option in Alzheimer's 
disease. Med Hypotheses 99:57-62. https://doi.org/10.1016/j. mehy.2016.12.006

125. Sorial ME, El Sayed NSED (2017) Protective effect of valproic acid in streptozotocin-induced sporadic Alzheimer's disease mouse model: possible involvement of the cholinergic system. Naunyn Schmiedebergs Arch Pharmacol 390(6):581-593

126. Owona BA, Zug C, Schluesener HJ, Zhang Z-Y (2019) Amelioration of behavioral impairments and neuropathology by antiepileptic drug topiramate in a transgenic Alzheimer's disease model mice, APP/PS1. Int J Mol Sci 20(12):3003

127. Long Z, Zeng Q, Wang K, Sharma A, He G (2016) Gender difference in valproic acid-induced neuroprotective effects on APP/ PS1 double transgenic mice modeling Alzheimer's disease. Acta Biochim Biophys Sin 48(10):930-938

128. Klee JL, Kiliaan AJ, Lipponen A, Battaglia FP (2020) Reduced firing rates of pyramidal cells in the frontal cortex of APP/PS1 can be restored by acute treatment with levetiracetam. Neurobiol Aging 96:79-86

129. Devi L, Ohno M (2013) Effects of levetiracetam, an antiepileptic drug, on memory impairments associated with aging and Alzheimer's disease in mice. Neurobiol Learn Mem 102:7-11

130. Zhang L, Wang L, Wang R, Gao Y, Che H, Pan Y, Fu P (2017) Evaluating the effectiveness of GTM-1, rapamycin, and carbamazepine on autophagy and Alzheimer disease. Med Sci Monit 23:801-808. https://doi.org/10.12659/msm.898679
131. Umeda T, Kimura T, Yoshida K, Takao K, Fujita Y, Matsuyama S, Sakai A, Yamashita M, Yamashita Y, Ohnishi K, Suzuki M, Takuma H, Miyakawa T, Takashima A, Morita T, Mori H, Tomiyama T (2017) Mutation-induced loss of APP function causes GABAergic depletion in recessive familial Alzheimer's disease: analysis of Osaka mutation-knockin mice. Acta Neuropathol Commun 5(1):59

132. Quiroga C, Chaparro RE, Karlnoski R, Erasso D, Gordon M, Morgan D, Bosco G, Rubini A, Parmagnani A, Paoli A, Mangar D, Camporesi EM (2014) Effects of repetitive exposure to anesthetics and analgesics in the Tg2576 mouse Alzheimer's model. Neurotox Res 26(4):414-421

133. Wang K, Fernandez-Escobar A, Han S, Zhu P, Wang J-H, Sun Y (2016) Lamotrigine reduces inflammatory response and ameliorates executive function deterioration in an Alzheimer's-like mouse model. Biomed Res Int 2016:1-9

134. Zhang M-Y, Zheng C-Y, Zou M-M, Zhu J-W, Zhang Y, Wang J, Liu C-F, Li Q-F, Xiao Z-C, Li S, Ma Q-H, Xu R-X (2014) Lamotrigine attenuates deficits in synaptic plasticity and accumulation of amyloid plaques in APP/PS1 transgenic mice. Neurobiol Aging 35(12):2713-2725

Publisher's Note Springer Nature remains neutral with regard to jurisdictional claims in published maps and institutional affiliations. 